\title{
Antioxidant and Anti-Collagenase Activity of Sargassum plagyophyllum Extract as an Anti-Wrinkle Cosmetic Ingredient
}

\author{
Karlah Lifie Riani Mansauda', Effionora Anwar ${ }^{2 *}$, Tati Nurhayati ${ }^{{ }^{*}}$
}

\section{Mansauda Karlah Lifie Riani ${ }^{1}$, Effionora Anwar ${ }^{2 *}$, Nurhayati, Tati ${ }^{3}$}

\section{'Master Student at Faculty of Pharmacy, University of Indonesia, INDONESIA. ${ }^{2}$ Professor at Faculty of Pharmacy, Doctor of Food Chemistry, University of Indonesia, INDONESIA. \\ ${ }^{3}$ Professor at Department of Aquatic Products Technology, Faculty of Fisheries and Marine Sciences, Bogor Agricultural University, INDONESIA.}

Correspondence

Prof. Dr. Effionora Anwar, MS., Apt.

Faculty of Pharmacy, Universitas Indonesia, Kampus UI Depok, 16424, West Java, INDONESIA.

Phone no : +62-21-7270031

E-mail: effionora.anwar@farmasi.ui.ac.id History

- Submission Date: 30-01-2018;

- Review completed: 05-03-2018;

- Accepted Date: 11-05-2018

DOI : 10.5530/pj.2018.5.157

Article Available online

http://www.phcogj.com/v10/i5

\section{Copyright}

(C) 2018 Phcog.Net. This is an openaccess article distributed under the terms of the Creative Commons Attribution 4.0 International license.

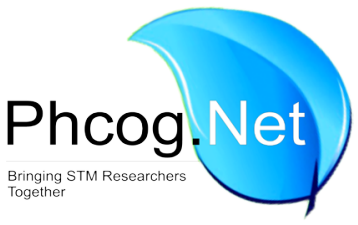

\begin{abstract}
Background: Sea algae are widely used as food and cosmetics in the world. There are several algae including brown algae which are us for human used to maintain health and skin care. Brown algae have various potential biological activities because contain substantial phytochemical constituent. Numerous report has identified phytochemical compound of Sargassum $\mathrm{sp}$. extract but the activity as anti-collagenase almost none. Objective: To study the antioxidant, and anti-collagenase activity of Sargassum plagyophyllum extract as active pharmaceutical ingredient for anti-wrinkle cosmetics. Methods: Sargassum plagyophyllum obtained from Pasauran Beach, Banten, West Java, Indonesia. The extract Sargassum plagyophyllum extracted with three concentration ethanol-water: (E1) ethanol $25 \%$, (E2) ethanol $50 \%$ and (E3) ethanol $75 \%$, by using maceration extraction method for $24 \mathrm{~h}$, thrice. The extract was evaluated include total phenolic content, antioxidant activity, and the best extract was tested for the anti-collagenase activity. Results: Total phenol in the extract were $0.588 \pm 0.01$ (E1), $0.272 \pm 0.01$ (E2), and $0.220 \pm 0.03$ (E3) mg PGE/ $100 \mathrm{~g}$ extract, respectively. Antioxidant activity of the extract $(50 \mathrm{mg} / \mathrm{mL})$ was $41,61 \pm 0,02 \%$ (E1), 39, $16 \pm 0,01 \%$ (E2), 37,58 $\pm 0,03 \%$ (E3) and ascorbic acid $78.03 \pm 0,65 \%(22.44 \mu \mathrm{g} / \mathrm{mL})$ as a standard. The best extract (E1) had inhibited the activity of collagenase by $54.46 \pm 0.37 \%$. Conclusion: The brown seaweed (Sargassum plagyophyllum) extract can be used as an active pharmaceutical ingredient for anti-wrinkles cosmetic

Key words: Anti-collagenase, Sargassum plagyophyllum, Antioxidant, Anti-wrinkle.
\end{abstract}

\section{INTRODUCTION}

Wrinkle can be caused by intrinsic and extrinsic factors. Intrinsic factors include metabolic processes, genetic factors, unbalanced antioxidant components in the skin and free radicals and hormonal factors. ${ }^{1}$ Extrinsic aging like wrinkle is caused by exposure UV radiation, stress, cigarettes, pollution, drugs and food. ${ }^{2}$ There are various ways to inhibit the skin aging process, one of them by inhibiting free radical activity. Materials that can be used to inhibit free radicals activity are called antioxidants. $^{3}$ In general plants and marine algae containing polyphenols, flavonoids, phenolic acids were also known to have the ability as anti-aging like antiwrinkle and antioxidant activity. ${ }^{4}$ One of natural antioxidants source was the brown seaweed (Sargassum sp.), ${ }^{5}$ and antioxidant activity mostly demonstrated by its polyphenols compound. ${ }^{6}$ Brown seaweed commonly content phlorotannin or phloroglucinol compounds that have antioxidant activity as radical scavenging activity (RSA) . ${ }^{7}$ Another study reported that phenol compounds in brown seaweed were more effective than a-tocopherol and almost comparable to synthetic antioxidants, BHA and BHT. ${ }^{8}$ Sargassum sp. has ability to inhibit and reactive oxygen species (ROS) by donating protons so as to speed up the process of free radical termination. ${ }^{9}$ ROS can derived by uv-ray from sun light and can damage the skin and cause wrinkle.

In this study, Sargassum plagyophyllum extracts might be one of natural ingredients that could be used for anti-wrinkle cosmetics. Therefore, determinate the total content of phenolic compound, antioxidant activity and the ability to inhibit collagenase enzyme is the importance factors to study as anti-wrinkle.

\section{MATERIALS AND METHODS}

\section{MATERIAL}

Sargassum plagyophyllum obtained from Pasauran Beach, Serang, Banten, West Java Indonesia. FolinCiocalteau Reagents (Sigma-Aldrich), Sodium Carbonate (Merck), Standard Phloroglucinol (Sigma-Aldrich), 2,2-Diphenyl-1-picrylhydrazyl (DPPH) (Sigma-Aldrich), Ascorbic acid standard (Sigma-Aldrich), N-[3-(2-furyl)acryloyl]-Leu-GlyPro-Ala (FALGPA) (Sigma-Aldrich), Epigallocatechingallate (EGCG) (Sigma-Aldrich), collagenase derived from Clostridium histolyticum (Chc) type IA (Sigma-Aldrich).
Cite this article: Mansauda KLR, Anwar E, Nurhayati T. Antioxidant and Anti-Collagenase Activity of Sargassum plagyophyllum Extract as an Anti-Wrinkle Cosmetic Ingredient. Pharmacog J. 2018;10(5):932-6. 


\section{METHODS}

To ensure species of Sargassum sp. that used in this research as Sargassum plagyophyllum was conducted determination at Oceanographic Research Centre, Indonesian Institute of Sciences (LIPI), Ancol, North Jakarta.

\section{Extraction of Sargassum sp.}

The method of extraction was done by maceration for $24 \mathrm{hr}^{10}$ using ethanol in different concentrations of $25 \%, 50 \%$ and $75 \%$ as a solvent. After filtered, the filtrate separated from residue, then evaporated by rotary evaporator at $40^{\circ} \mathrm{C}$ until produced viscous extract. To produce the dry extract evaporation process was continued by using a water bath.

\section{Phytochemical Screening of Extract Sargassum sp.}

Qualitative analysis of the S. plagyophyllum extract determined by ferric chloride test for phenol, magnesium turning test for flavonoids, and Meyer and Dragendorff reagents for alkaloids, according to previous study. ${ }^{11}$

\section{Total Phenolic Content (TPC) of S. plagyophyllum extract}

Total Phenolic Content (TPC) of the extract was determined using Folin-Ciocalteu method. ${ }^{5}$ To $0.5 \mathrm{ml}$ of Sargassum sp. extract was added one $\mathrm{ml}$ of $10 \%$ folin-ciocalteu solution. The solution was mixed by vortex and incubated in dark place with room temperature for $5 \mathrm{~min}$. After that, two $\mathrm{ml}$ of $7.5 \%$ sodium carbonate solution was added and shaken until homogeneous. The solution was stored for $70 \mathrm{~min}$ and the absorbance were measured at $707 \mathrm{~nm}$ using a UV-Vis spectrometer. Total phenolic content was calculated based on a standard curve of phloroglucinol. The curve was made by plotting concentration (ppm) versus absorbance. Total phloroglucinol was expressed in mg Phloroglucinol Equivalents (PGE) per $100 \mathrm{~g}$ of dried extract.

\section{Antioxidant activity of S. plagyophyllum extract}

Antioxidant activity was tested using DPPH radical-scavenging activity method ${ }^{12}$ with modification. $0.5 \mathrm{ml}$ of sample (with different concentrations) was added three $\mathrm{ml}$ of DPPH-ethanol solution. The mixture of DPPH-sample was homogenized and kept at room temperature also protected from light for $30 \mathrm{~min}$, then measured using UV-Vis spectrophotometer at $517 \mathrm{~nm}$. The same treatment was used to determined ascorbic acid as control. The antioxidant activity is calculated by following equation:

$$
\% \text { inhibition }=\frac{\mathrm{As}-\mathrm{Ac}}{\mathrm{As}} \times 100
$$

Information: $\mathrm{A}_{\mathrm{s}}$ is absorbance and $\mathrm{A}_{\mathrm{c}}$ absorbance of sample solution without DPPH.

\section{Anti-Collagenase activity of S. plagyophyllum extract}

Anti-collagenase activity of $S$. plagyophyllum extract was evaluated following the Wittenauer method ${ }^{13}$ with modification. $50 \mu \mathrm{L}$ trisine buffer solution ( $\mathrm{pH} 7.5), 50 \mu \mathrm{L}$ of sample and $50 \mu \mathrm{L}$ of enzyme $(125 \mathrm{U} / \mathrm{ml} \mathrm{ChC}$, type IA) were added into 96-well microplate. To start the reaction was added $50 \mu \mathrm{L} \mathrm{N}$ - (3- [2-Furyl] -acryloyl)-Leu-Gly-Pro-Ala (FALGPA) $0.5 \mathrm{mM}$. The solution was then incubated for 15 min after the reaction started. The decrease of FALGPA absorbance was monitored at $340 \mathrm{~nm}$ in the microplate reader at a constant temperature of $25^{\circ} \mathrm{C}$ after the addition of FALGPA. Positive controls were used epigallocatechin gallate (EGCG), percentage inhibition was calculating by:

$$
\text { Percentage inhibition }(\%)=1-\frac{\mathrm{O}_{s}}{\mathrm{O}_{c}} \times 100
$$

Information: OS is the corrected absorbance enzyme in the presence of samples, and $\mathrm{OC}$ is the corrected absorbance of enzyme without samples.

\section{RESULTS}

Sample that used in this study is Sargassum plagyophyllum based on determination at The Oceanographic Research Centre $\left(\mathrm{P}_{2} \mathrm{O}\right)$ Indonesian Institute of Sciences (LIPI) (Figure 1). Qualitative analysis for S. plagyophyllum showed that brown seaweed extracted with ethanol $25 \%$, $50 \%$, and $75 \%$ showed also positive contained phenol, flavonoids, and alkaloids.

\section{Total Phenolic Content (TPC) of S. plagyophyllum extracts}

The yield of total phenol in the extract was $0.588 \pm 0.01 \mathrm{mg}$ PGE/ $100 \mathrm{~g}$ for extract ethanol $25 \%$ (E1), $0.272 \pm 0.01 \mathrm{mg}$ PGE/ $100 \mathrm{~g}$ for extract ethanol 50\% (E2), and $0.220 \pm 0.03 \mathrm{mg}$ PGE/ $100 \mathrm{~g}$ for extract ethanol $75 \%$ (E3) (Figure 2). Ethanol 25\% was proved more effected to extract phloroglucinol compounds in the brown seaweed S. plagyophyllum than extract with different solvent.

\section{Antioxidant activity of S. plagyophyllum extracts}

Antioxidant activity was tested using DPPH radical-scavenging activity method. The antioxidant activity of $S$. plagyophyllum extracts $(50 \mathrm{mg} / \mathrm{mL})$ was $41,61 \pm 0,02 \%$ for extract ethanol $25 \%$ (E1), 39,16 $\pm 0,01 \%$ for extract ethanol 50\% (E2), 37,58 $\pm 0,03 \%$ for extract ethanol $75 \%$ (E3) and ascorbic acid $78.03 \pm 0,65 \%$ (at $22.44 \mu \mathrm{g} / \mathrm{mL}$ ) as antioxidant activity comparison (Figure 3). It showed that ethanol 25\% extract of S. plagyophyllum had the highest antioxidant activity than other extracts. Based on these the data, concentration of phenol content in the extracts consistent with their antioxidant activity but were no higher than ascorbic acid as the standard.

\section{Anti-Collagenase activity of S. plagyophyllum extract}

Result showed that $50 \mu \mathrm{g} / \mathrm{mL}$ S. plagyophyllum extract inhibited $54.46 \pm$ $0.37 \%$ activity of collagenase enzyme. Relationship between anti-collagenase activity extracts and concentration of the extracts can be seen in Figure 4 with $\mathrm{y}=0.2386 \mathrm{x}+42.464$ and coefficient of determination $\mathrm{R}^{2}=0.9136$. Where $\mathrm{Y}$ is the yields of anti-collagenase, and $\mathrm{X}$ is the concentration of extract.

\section{DISCUSSION}

Sample that used in this study is true Sargassum plagyophyllum based on determination at The Oceanographic Research Centre $\left(\mathrm{P}_{2} \mathrm{O}\right)$ Indonesian Institute of Sciences (LIPI), and have length of herb $44.5 \mathrm{~cm}$, leaves length $6.1 \mathrm{~cm}$ and a width $1.2 \mathrm{~cm}$ (Figure 1). Phytochemical qualitative analysis of chemical substances all parts of plants indicated that they have contained alkaloids, flavonoids, and phenols. Qualitative tests were performed to identify the pharmacological compounds present in the extract using a simple method. ${ }^{14}$ Phenol is one of the compounds that can prevent aging, cardiovascular disease, and protect from free radicals. ${ }^{15}$ Qualitative analysis for S. plagyophyllum showed that brown seaweed extracted with ethanol $25 \%, 50 \%$, and $75 \%$ showed also positive contained phenol, flavonoids, and alkaloids. ${ }^{1}$ Total phenol in the extract was $0.59 \pm$ 0.01 (E1), $0.27 \pm 0.01$ (E2), and 0.22 $\pm 0.03 \mathrm{mg}$ PGE/ $100 \mathrm{~g}$ (E3), respectively (Figure 2). The measurement of phenol content was conducted by Folin-Ciocalteu method because it was a quick and simple method to determine the phenolic content of a sample. ${ }^{16}$ The most important phenolic compounds contained in the extract of seaweed is phlorotannin. Phenolic compounds had been reported to have antioxidant properties. Earlier reports revealed that polyphenols in brown seaweed extracts had antioxidant activity. ${ }^{17}$ To obtain extracts with maximum phenolic content, the selection of suitable solvents is an important factor in the extraction process. In this study, we used ethanol. Ethanol widely used in the extraction of polyphenol compounds because of its non-toxic nature. The content of phloroglucinol in the S. plagyophyllum extracts in various concentration of ethanol can be found in Figure 1. It showed that 
S. plagyophyllum immersed in $25 \%$ ethanol (E1) had the most phenolic compounds of $0.59 \pm 0.009 \mathrm{mg}$ PGE/ $100 \mathrm{~g}$ extract compared to other ethanol concentration and higher the water content in solvent the more phloroglucinol was drawn.

Water as a solvent can attract phlorotannin with strong polarity. It can have affected algae cell to swell and caused the substance out of the cell, indicated that polarity of the solvent was very important in choosing solvent for the extraction process for polar substances. ${ }^{18}$ According to previous study Sargassum serratum was extracted with ethanol $100 \%$ could extracted phenolic compound $(4.102 \pm 0.005 \mathrm{mg}$ phloroglucinol equivalent/g extract). ${ }^{18}$ On the other hand, ethanol $25 \%$ was proved more effected to extract phloroglucinol compounds in the brown seaweed S. plagyophyllum. There were several factors that affected such a difference, it is not only polarity factor but also difference kind of the structure of phlorotannin in algae, also depending on the geographical area of collection and the genetic variation of the alga itself ${ }^{19}$ for example, TPC for $F$. serratus that was collected from Finnavarra, Clare, Ireland has $18.055 \mathrm{mg}$ PGE/ $100 \mathrm{~g}$ sample ${ }^{20}$ meanwhile, TPC for F. serratus was collected from Hvassahraun coastal area, Iceland has $24.0 \mathrm{~g}$ PGE/ $100 \mathrm{~g}$ sample. ${ }^{21}$ Plants with different species are also shown to have different antioxidant activity although included in the same genus. ${ }^{22}$

Antioxidant activity was tested using DPPH radical-scavenging activity method, this method was measured the occurrence of color changes due

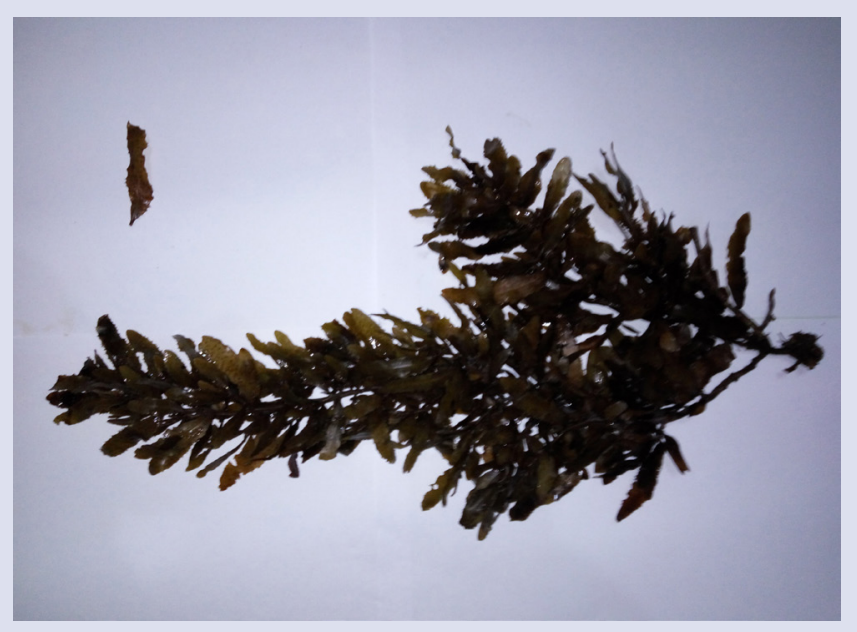

Figure 1: Brown seaweed (Sargassum plagyophyllum) obtained from Pasauran Beach, Serang, Banten.

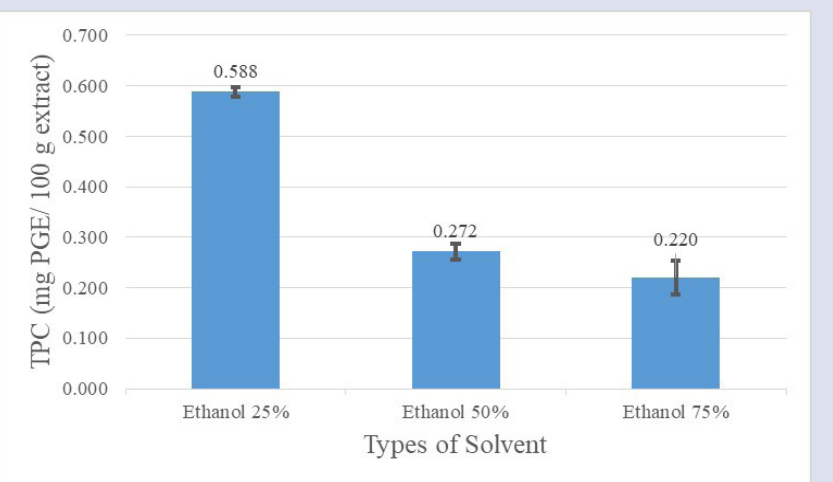

Figure 2: Total Phenolic Content (TPC) of Sargassum plagyophyllum extracts

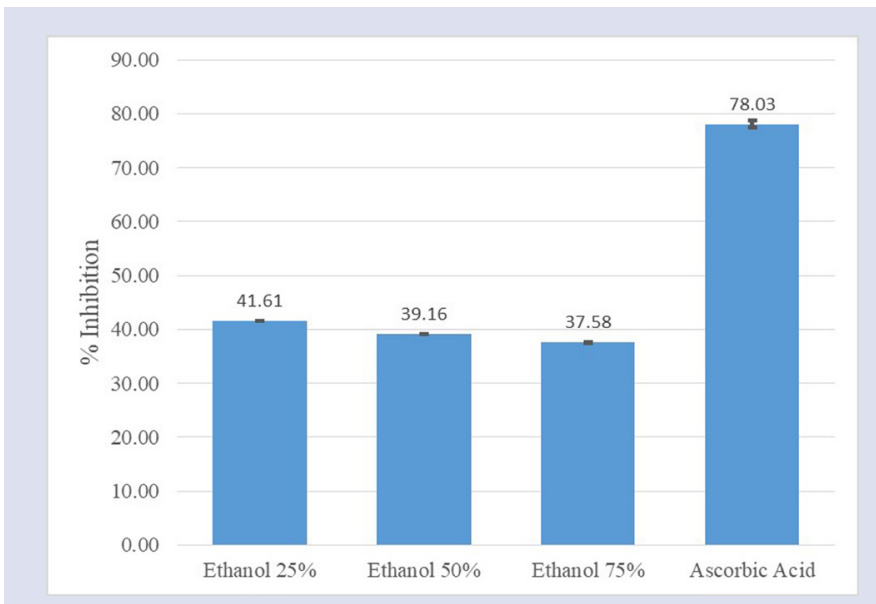

Figure 3: Antioxidant activity of Sargassum plagyophyllum extracts (at $50 \mathrm{mg} / \mathrm{mL}$ ) and ascorbic acid (at $22.44 \mu \mathrm{g} / \mathrm{mL}$ )

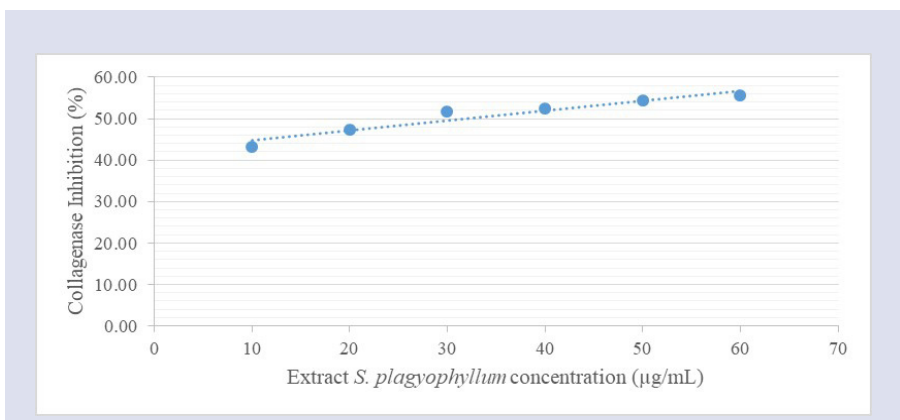

Figure 4: Relationship between anti-collagenase activity extracts and concentration of the extracts.

to the neutralization reaction between free radical molecules by donating hydrogen $(\mathrm{H})$ atom. ${ }^{23,24}$ One of the most common method for testing preliminary antioxidant activity of plant extracts is DPPH radical-scavenging. ${ }^{25}$ In this test, the antioxidant activity of S. plagyophyllum extract $(50 \mathrm{mg} / \mathrm{mL})$ was $41,61 \pm 0,02 \%$ (E1), $39,16 \pm 0,01 \%$ (E2), $37,58 \pm 0,03 \%$ (E3) and ascorbic acid $78.03 \pm 0,65 \%(22.44 \mu \mathrm{g} / \mathrm{mL})$ as antioxidant activity comparison (Figure 3.). Extract ethanol 25\% of S. plagyophyllum had the highest antioxidant activity than other extract. Based on these the data, indicated the higher TPC value of S. plagyophyllum the higher its antioxidant activity (E1). This result supported by previous studies who found that there are high correlations between concentrations of TPC and antioxidant activity. ${ }^{17,26}$

\section{Anti-Collagenase activity of S. plagyophyllum extract}

Activity of anti-collagenase was determined by with microplate readers at $340 \mathrm{~nm}$. Collagenase assay only conducted to ethanol 25\% S. plagyophyllum extract. Result showed that $50 \mu \mathrm{g} / \mathrm{mL}$ S. plagyophyllum extract inhibited $54.46 \pm 0.37 \%$ activity of collagenase enzyme. Relationship between anti-collagenase activity extracts and concentration of the extracts can be seen in Figure 4. Pientaweeratch ${ }^{27}$ revealed that extracts offered anti-aging or anti-wrinkle properties in different mechanisms. Amla showed moderate anti-collagenase activity with the highest phenolic content and antioxidant property. Sapota showed the higher anticollagenase activity and anti-elastase activity with moderate antioxidant effect. ${ }^{27}$ Thus, extracts might be added as a mixture to gain the anti-wrinkle effects. Study on phenolic content might be related to the antioxidants of an extract but has no correlation with anti-proteinase activity ${ }^{27,28}$ for the example pomegranate showed no phenolic content but observed inhibit 
Anwar, et al.: Antioxidant and Anti-Collagenase Activity of Sargassum plagyophyllum Extract as an Anti-Wrinkle Cosmetic Ingredient

$50 \%$ collagenase at $0.5 \mu \mathrm{l}$ of pomegranate peel extract. ${ }^{29}$ Therefore, although the extract has a low TPC value, it is necessary to screen antiproteinase activity such as anti-collagenase to determine the anti-aging properties of the extracts. ${ }^{27}$ It was indicated that structure and physicochemical properties of the substance can influence activity pharmaceutical ingredient in pharmaceutical product like drug or cosmetics.

\section{CONCLUSION}

The present study revealed Sargassum plagyophyllum extracts as a new alternative potent anti-collagenase activity for active pharmaceutical ingredient cosmetic anti-wrinkle. We presume that the collagen enzymes inhibitory effects of Sargassum plagyophyllum extracts are independent on their total phenolic compound and antioxidant activity. Further research on anti-proteinase activity and determination of active compounds related to anti-wrinkle are necessary to treat wrinkle.

\section{ACKNOWLEDGEMENT}

The researchers highly thankful to University of Indonesia for supporting financial especially to PITTA (Publikasi Internasional Terindeks Untuk Tugas Akhir Mahasiswa) Grant Research 2017.

\section{CONFLICT OF INTEREST}

The authors declare that there is no conflict of interest.

\section{ABBREVIATIONS}

BHA: Butylated hydroxyanisole; BHT: Butylated hydroxytoluene; Chc: Clostridium histolyticum; DPPH: 2,2-Diphenyl-1-picrylhydrazyl; EGCG: Epigallocatechingallate; FALGPA:N-[3-(2-furyl)acryloyl]-LeuGly-Pro-Ala; F. serratus: Fucus serratus; LIPI : Indonesian Institute of Sciences; PGE : Phloro Glucinol Equivalents; P2O : The Oceanographic Research Centre; ROS : Reactive Oxygen Species; RSA : Radical Scavenging Activity; S. plagyophyllum: Sargassum plagyophyllum; TPC : Total Phenolic Content; UV-Vis spectrophotometer: UltravioletVisible spectrophotometer.

\section{REFERENCES}

1. Chattuwatthana T, Okello E. Anti-collagenase, Anti-elastase and Antioxidant Activities of Pueraria candollei var. mirifica root Extract and Coccinia grandis Fruit Juice Extract: An in vitro study. European J Med Plants. 2015;5(4):318-27.

2. Putranti RI. Skrining Fitokimia dan Aktivitas Antioksidan Ekstrak Rumput Laut Sargassum duplicatum dan Turbinaria ornata dari Jepara. Thesis. Universitas Dipenegoro Semarang, Indonesia. 2013

3. Thring TS, Hili P, Naughton DP. Anti-collagenase, anti-elastase and anti-oxidant activities of extracts from 21 plants. BMC Complement Altern Med. 2009;9(1):27.

4. Cunningham WBR, Maibah H. Aging and Photoaging. In: Textbook of Cosmetic Dermatology. Francis Taylor $3^{\text {rd }}$ ed. London. 2005;443.

5. Ye $\mathrm{H}$, Zhou $\mathrm{C}$, Sun $\mathrm{Y}$, Zhang $\mathrm{X}$, Liu J, Hu Q, et al. Antioxidant activities in vitro of ethanol extract from brown seaweed Sargassum pallidum. Eur Food Res Technol. 2009;230(1):101-9.

6. Firdaus M. Indeks Aktivitas Antioksidan Ekstrak Rumput Laut Coklat (Sargassum aquifolium). Jphpi. 2013;16(1):42-47.

7. Cahyaningrum K, Husni A, Budhiyanti SA. Aktivitas Antioksidan Ekstrak Rumput Laut Coklat (Sargassum polycystum). ARGITECH. 2016;36(2):137-44.

8. Demirel Z, Yilmaz-Koz FF, Karabay-Yavasoglu UN, Ozdemir G, Sukatar A. Antimicrobial and Antioxidant Activity of Brown Algae from Yhe Aegean Sea. Journal of Serbian Chemical Society. 2009;74(6):619-28.
9. Wei, Yuxi Li, Zhi en, Yingfen Xu, Zuhong. Inhibition of mouse liver lipid peroxidation by high molecular weight phlorotannins from Sargassum kjellmanianum. Journal of Applied Phycology. 2003;15(6):507-11.

10. Kim MM, Van Ta Q, Mendis E, Rajapakse N, Jung WK, Byun HG, et al. Phlorotannins in Ecklonia cava extract inhibit matrix metalloproteinase activity. Life Sci. 2006;79(15):1436-43.

11. Harborne JB. Metode Fitokimia: Penuntun Cara Modern Menganalisis Tumbuhan. Institut Teknologi Bandung. (Translated by Kosasih Padmawinata and Iwang Soediro). $2^{\text {nd }}$ ed. Bandung. 1987.

12. Ye $\mathrm{H}$, Zhou $\mathrm{C}$, Sun $\mathrm{Y}$, Zhang $\mathrm{X}$, Liu J, Hu Q, et al. Antioxidant activities in vitro of ethanol extract from brown seaweed Sargassum pallidum. Eur Food Res Technol. 2009;230(1):101-9.

13. Wittenauer J, Mackle S, Submann D, Schweiggert-Weisz U, Carle R. Inhibitory effects of polyphenols from grape pomace extract on collagenase and elastase activity. Fitoterapia. 2015;101:179-87.

14. Malik B, Pirzadah TB, Tahir I, Rehman RU. Chemo-profiling, Antioxidant potential and Ionomic analysis of Cichorium intybus L. Pharmacog J. 2017;9(6):917-28.

15. Zhang J, Yuan K, Zhou WI, Zhou J, Yang P. Studies on the active components and antioxidant activities of the extracts of Mimosa pudica Linn. From southern China. Phcog Mag. 2011;7(25):35-9.

16. Jeyapragash D, Subhashini P, Raja S, Abirami K. Evaluation of in-vitro Antioxidant Activity of Seagrasses: Signals for Potential Alternate Source. Free Radicals Antioxidants. 2016;6(1):77-89.

17. Luo H, Wang B, Yu C, Qu Y, Su C. Evaluation of antioxidant activities of five selected brown seaweeds from China. J Med Plant Res. 2010;4(23):2557-65

18. Boi VN, Cuong DX, Vinh PT. Effects of extraction conditions over the phlorotannin content and antioxidant activity of extract from brown algae Sargassum serratum. Free Radicals Antioxidants. 2017;7(1):115-22

19. Koivikko R. Brown Algal Phlorotannins. Improving and Applying Chemical Methods Turku, Finland; 2008. 47.

20. Heffernan N, Brunton NP, FitzGerald RJ, Smyth TJ. Profiling of the molecular weight and structural isomer abundance of macroalgae-derived phlorotannins Mar Drugs. 2015;13(1):509-28.

21. Wang T, Jónsdóttir R, Ólafsdóttir G. Total phenolic compounds, radical scav enging and metal chelation of extracts from Icelandic seaweeds. Food Chem. 2009;116(1):240-8

22. Zhang J, Yuan K, Zhou WI, Zhou J, Yang P. Studies on the active components and antioxidant activities of the extracts of Mimosa pudica Linn. from southern China. Phcog Mag. 2011;7(25):35-9.

23. Molyneux P. The use of the stable free radical diphenylpicrylhydrazyl (DPPH) for estimating antioxidant activity. Songklanakarin J Sci and Technol. 2004;26(2):211-9

24. Kumar D, Kumar S, Singh J, Narender, Rashmi, Vashistha B, et al. Free Radical Scavenging and Analgesic Activities of Cucumis sativus L. Fruit Extract. J Young Pharm. 2010;2(4):365-8.

25. Apraj VD, Pandita NS. Evaluation of skin anti-aging potential of Citrus reticulata blanco peel. Phcog Res. 2016;8(3):160-8.

26. Chunchom S, Talubmook C, Deeseenthum S. Antioxidant Activity, Biochemical Components and Sub-Chronic Toxicity of Different Brown Rice Kefir Powders. Pharmacogn J. 2017;9(3):388-94.

27. Pientaweeratch S, Panapisal V, Tansirikongkol A. Antioxidant, anti-collagenase and anti-elastase activities of Phyllanthus emblica, Manilkara zapota and silymarin: an in vitro comparative study for anti-aging applications. Pharm Biol. 2016;54(9):1865-72.

28. Thring TSA, Hili P, Naughton DP. Anti-collagenase, anti-elastase and anti-oxidant activities of extracts from 21 plants. BMC Complementary and extracts from 21 plants. BMC Complement Altern Med. 2009; 9(1):27-11.

29. Aslam MN, Lansky EP, Varani J. Pomegranate as a cosmeceutical source: Pomegranate fractions promote proliferation and procollagen synthesis and inhibit matrix metalloproteinase-1 production in human skin cells. J Ethnopharmacol. 2006;103(3):311-8 


\section{GRAPHICAL ABSTRACT}

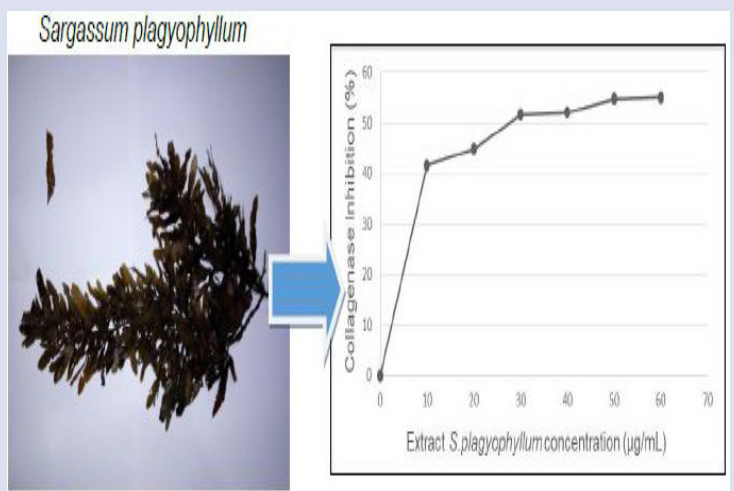

SUMMARY

- This study revealed that Sargassum plagyophyllum have shown anti-collagenase activity against collagenase from Clostridium histolyticum.

- Collagen enzymes inhibitory effects of Sargassum plagyophyllum extracts are independent on their total phenolic compound and antioxidant activity.

- Sargassum plagyophyllum reported being a new promising alternative that can be used as anti-wrinkle ingredient.

\section{ABOUT AUTHORS}

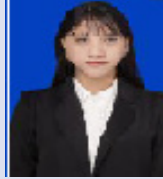

Karlah Lifie Riani Mansauda: Currently a master student at Faculty of Pharmacy, University of Indonesia.

Effionora Anwar: Professor and lecturer at Department of Pharmaceutical Technology, Faculty of Pharmacy, University of Indonesia.

Tati Nurhayati: Professor and lecturer at Department of Aquatic Products Technology, Faculty of Fisheries and Marine Sciences, Bogor Agricultural University. 